\title{
ELDERLY HEALTH: PROFESSIONAL TRAINING AND PERFORMANCE IN PRIMARY HEALTH CARE
}

\author{
SAÚDE DO HOMEM IDOSO: FORMAÇÃO PROFISSIONAL E ATUAÇÃO NA \\ ATENÇÃO PRIMÁRIA A SAÚDE
}

\author{
Maria Nauside Pessoa da SILVA ${ }^{1}$; Eliana Campelo LAGO ${ }^{2}$; Inez Sampaio NERY ${ }^{1}$; \\ Camila Aparecida Pinheiro Landim ALMEIDA³; Fabrício Ibiapina TAPETY³; \\ Aíka Barros Barbosa MAIA ${ }^{4}$; Erisonval Saraiva da SILVA ${ }^{1}$ \\ 1. Federal University of Piaui, Teresina, Piaui, Brazil. nauside@yahoo.com.br; 2. State University of Maranhão-Caxias -MA.; \\ 3.University Center UNINOVAFAPI, Teresina, Piaui, Brazil; 4. State University of Piaui, Teresina, Piaui, Brazil. Universidade Federal \\ do Piauí - UFPI. Campus Universitário Ministro Petrônio Portella, Bairro Ininga - Teresina - PI.
}

\begin{abstract}
To identify the influences of the professional training process for action in the Family Health Strategy (FHS) related to the health of the elderly man. Exploratory descriptive research, carried out with 20 professionals, from a Brazilian Northeast municipality from October to December 2014. The data collection was performed through a questionnaire, following the statements were processed in the software IRaMuTeQ, analyzed by the Descending Hierarchical Classification. Three classes emerged: Influences of the professional training process on elderly health care; Health care for the elderly; Actions developed in the family health strategy in the implementation of the national policy of comprehensive health care for the elderly. The findings suggest improved knowledge, lack of resources and medical specialties, evidenced the complexity of the actions developed by health professionals.
\end{abstract}

KEYWORDS: Staff Development. Men's Health. Elderly. Primary Health Care. Qualitative Research.

\section{INTRODUCTION}

The National Policy on Integral Attention to Human Health (PNAISH) was prepared by the Ministry of Health in 2008, with the main assumption of facilitating and expanding the access of men to basic health care services, with the purpose of promoting the health, disease prevention and rehabilitation of the elderly male population. In the Family Health Strategy, health professionals play a fundamental role in the implementation of public health policies that benefit the attendance of specific groups (ALELUIA et al., 2017).

The PNAISH reports that the male population is not well received by the Primary Care services, the entrance of this public into the health system sometimes occurs through outpatient and hospital care of medium and high complexity, when they already show some health problem, a factor that leads to high morbidity and mortality rates due to the delay in the search for care. The resistance of this population segment in the search for care in primary care presents several reasons, such as institutional barriers, when they do not offer a differentiated care to this public and the sociocultural barriers, since man does not usually take good care of his own health (SHUBERT et al., 2018).
The man has specific characteristics that need to be understood and respected, so that you can see the different looks and health of models, as well as how to view the process of health and illness that manifest in this social group and understand the determinants that overlap (AGUIAR; SANTANA; SANTANA, 2016). The elderly man presents several peculiarities related to the other age groups and, therefore, the health evaluation of this public should be carried out with the objective of identifying the several problems that emerge from the main complaint, that interfere in the health disease process (MINAYO et al., 2015).

In order to satisfy patients 'needs, health professionals should be holders of scientific knowledge, with the purpose of developing a practice according to the patients' needs, based on theoretical/practical knowledge to perform technical procedures, to meet the patient's manifest demand the elderly, to be able to understand and give explanations about their state of health and the process of illness (FERRAZ; KRAICZYK, 2017).

The Family Health Strategy (FHS) presents as its principles and guidelines the territory assigned to it, in order to allow planning, decentralized programming and the development of sectoral and intersectoral actions with impact on the determinants and determinants of the health of the community that constitute in accordance with the 
principle of equity, enabling universal and continuous access to health services, welcoming users and promoting the linkage and establishment of mechanisms that ensure accessibility, assuming that the health unit should receive and listen to all the people who seek their services, in a universal way and without excluding differentiations (BRASIL, 2011).

As far as professional training is concerned, the FHS is not very attractive as a field of training and professional activity and also in front of the social imaginary in which the superiority of the care that should be the most specialized is prevailing, this can be one of the elements that affects the perception of doctors and nurses regarding professional recognition. However, changes undertaken by the FHS are reflected in the level of satisfaction and improvements in the actions developed in the care and quality of health care provided by professionals (RIBEIRO; GOMES; MOREIRA, 2017).

In this sense, this study aimed to identify the influence of the process of professional training for action in the Family Health Strategy related to the health of the elderly man.

\section{MATERIAL AND METHODS}

The guidelines for carrying out research involving human subjects contained in Resolution 466 of the National Health Council were respected. The approval of the Ethics Committee of the institution in which the study was carried out, opinion no. 665.705, as well as the beginning of the interview, the Free and Informed Consent of the participants.

This is a descriptive, exploratory, qualitative approach, carried out with 20 Health Professionals working in the Family Health Strategy. Inclusion criteria were considered: not be effective professionals of the Municipal Health Secretariat of Rio Grande do Piauí, with minimum time of 01 (one) year of action in the Family Health Strategy, that participate in actions of health promotion and prevention of diseases. As a criterion for exclusion, professionals with less than one year of service in the FHS, who are temporarily hired, trainees or volunteer services.

The interviews were performed in the morning and afternoon shifts, in an isolated room of the institution, between October and December 2014. The interviews were personal, realized in a separate room and had an average duration of 20 minutes. They were performed by the principal investigators after training. At the end of each interview, it was asked whether any participant would like to give up participating in the research or change something that was said, yet no member gave up or requested changes. Data were collected through a semi-structured interview, which, after consent, were recorded in digital equipment of type MP4 and subsequently transcribed in full.

To maintain the anonymity of the study participants, they were named according to their area of practice, such as (CHA) for Community Health Agents and (N) for Nurses; followed by numerals $01,02,03$ and successively, according to the number of each professional class searched.

In order to analyze the data, we used the software IRaMuTeQ, free software and developed under the logic of open source, which organizes the distribution of vocabulary in a way that is easy to understand. The program identifies and reformats text units, transforming Initial Context Units (UCUs) into Elementary Context Units (UCEs) (QUEIROZ; SOUSA, 2017; JESUS et al., 2017; MATOS et al., 2018). The use of softwares in qualitative research has aided the apprehension of the research object (RODRIGUES et al., 2017; QUEIROZ; SOUSA, 2017; JESUS et al, 2017; MATOS et al., 2018).

and has been emphasizing more and more in the scientific literature, with IRaMuTeQ being an important highlight among them (MATOS et al, 2018; QUEIROZ et al., 2018).

For the textual analysis, the descending hierarchical classification method was used, in which the texts were classified according to their respective vocabularies and the set of texts was divided by the frequency of reduced forms. Through this classification, the analysis sought to obtain text segment classes, which, in addition to vocabulary manifesting similar between them, had vocabulary that was different from the text segments of the other classes; the relationship between classes is illustrated in the dendrogram (RODRIGUES et al., 2017; QUEIROZ; SOUSA, 2017; JESUS et al., 2017; MATOS et al., 2018).

For the configuration of the classes, the authors considered lexical forms with frequency higher than twice the mean number of occurrences in the corpus and with chi-square $(\chi 2)$ with significance value $\mathrm{p} \leq 0.01$, which, according to Fisher's Significance Scale, corresponds to strong evidence (JESUS et al, 2017; MATOS et al., 2018; QUEIROZ et al., 2018). The use of software is not an absolute data analysis method, but a procedural tool that facilitates the analysis. The researcher is responsible for interpretation and conclusion based 
Elderly health...

on their view of the findings (QUEIROZ et al., 2018).

\section{RESULTS}

Considering the Describing Method (CHD), we obtained the classes of text segments that present similar vocabulary to each other. In this way three
SILVA, M. N. P. et al.

classes were elaborated, namely class 1 - Influences of the process of professional formation in the Attention to the Health of the Aged Man; class 2 Health care for the elderly; Class 3 - Actions developed in the Family Health Strategy in the Implementation of the National Policy of Integral Attention to the Health of the Aged Man.

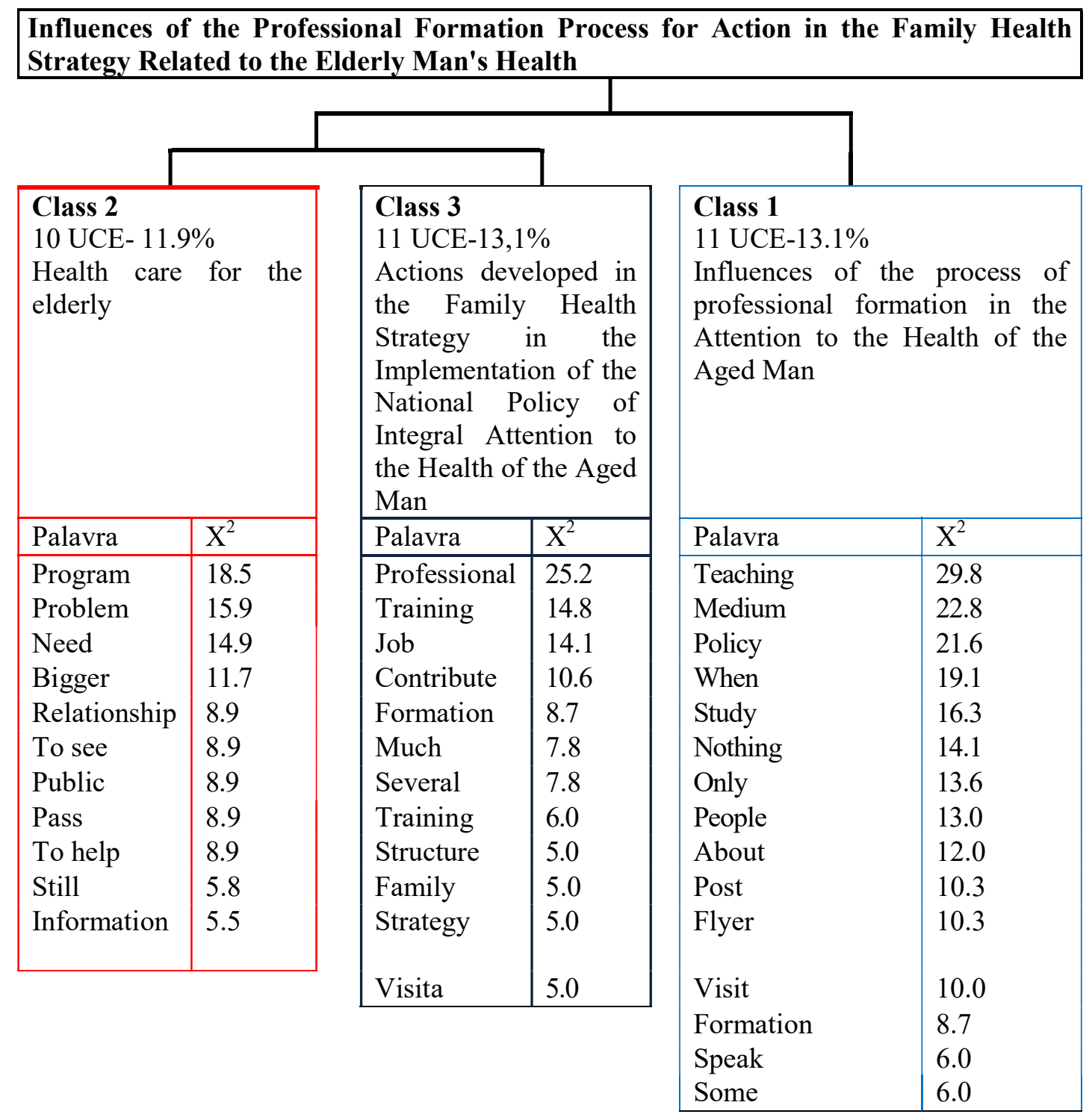

Figure 1. Thematic structure of the influences of the Professional Formation Process for action in the Family Health Strategy related to the health of the elderly man

Figure 1 presents the Dendrogram of the relation between the classes of text segments that present similar vocabulary to each other. It represents the thematic structure of the influence of the process of professional formation in the action in the Family Health Strategy related to the health of the elderly man. From the presented data, the classes to be worked out in the study were defined and elaborated.

The study sought to know the influences of the professional training process for action in the Family Health Strategy related to the Health of the Elderly, to identify the health care of the elderly and to describe the actions developed in the Family Health Strategy in the implementation of the 
Elderly health...

Comprehensive Care Policy to the Health of the Elderly Man.

Class 1- Influences of the process of professional formation in the Attention to the Health of the Aged Man

In class 1 , professionals present in their speech the implications of their training in their practice regarding the care of men in health services.

Seeing the need to take better care of the health of the man [...] stimulating the participation of this public. [...] improvement of programs giving greater attention to the man in the third age. [...] influences the conviction of the knowledge of this male population of the importance of adherence to the programs of attention to human health in view of the benefits of acquiring information and therapeutic clinical practices for better care. [...] improved my knowledge to help bring information to users who do not care about their own health because there are still barriers and prejudices [...].

\section{Class 2- Health care for the elderly}

With regard to health care for the elderly, it has established two strands, the first describes how health professionals approach users to provide care, and the second deals with the difficulties encountered in developing quality care as described: Directing him to seek the health services that they come to do the examinations [...] should be looking for a urologist or at least make an ultrasound or blood test specific prostate antigen. [...] as a Community Health Agent, what I do is to advise men to seek more health services. [...] the elderly man needs more attention because there are many who already have several diseases such as diabetes and hypertension and need to schedule the appointments and take the exams every year. domicile [...] health education, they are very attentive and always participate.

In the approach that infers the difficulties encountered by health professionals to provide quality assistance to users, it can be seen in the following statements:

They are the lack of resources to work the health of men, lack of training, lack of examinations, lack of urologist doctors, we have no structure. [...] the elderly man finds it difficult to seek health services, perhaps because they lack knowledge and because they do not have a health policy for men in the municipality. [...] lack of training on man's policy and lack of medical specialists to do some consultations and exams have to go to another city. [...] difficulties in making men aware of health
SILVA, M. N. P. et al.

services, difficulties in carrying out exams and specialized consultations.

The challenges faced by professionals in the Family Health Strategy in relation to the accessibility of the male segment are constant, among them the support of the management of the health units, the fragility of training and training of the workers in the area.

It is observed in class 2 that health professionals are willing to provide a good assistance to the male public, directing them to seek health services, health education, scheduling appointments and marking examinations. However, there are several obstacles, among them, lack of resources and structure, absence of a policy in the municipality aimed at this public, lack of training of professionals, lack of specialized doctors and difficulties in carrying out exams.

Class 3 - Actions developed in the Family Health Strategy in the Implementation of the National Policy of Integral Attention to the Health of the Aged Man

In this class 3 , we observe the complexity of the actions developed by health professionals, which extends from the concern with the quality of life of the male audience in the third age, to the actions developed for the prevention of diseases and incapacities, as well as the disquiet about discrimination and abandonment of this public.

With regard to the actions developed by professionals, the following is:

[...] lectures on healthy eating for hypertensive and diabetic patients. [...] home care [...] work in groups of elderly people who carry out some type of activity. [...] vaccination campaigns [...] prevention of communicable diseases and prevention of prostate cancer. [...] campaigns to talk about tuberculosis in the elderly vaccine, prevention of smoking [...] hypertension and diabetes. [...] physical activity walking and in the gym for the elderly.

As he describes in the statements of the interviewees about the actions developed, it can be noted that they extend from the promotion of health, such as lectures, campaigns and physical activities, as well as in the prevention of communicable diseases and prostate cancer to home care.

Concerning the concern with the quality of life of the male pubic, it was observed in the following speeches:

[...] in the struggle for the conservation of the health and quality of life of these people, behavioral changes in the search for health promotion. [...] 
there are some aspects that favor this situation as the medical and technological advances that contribute in part to the increase in the life expectancy of the elderly.

Another fundamental point that was observed in this class 3 is that health professionals showed concern about the living, discrimination and abandonment of elderly men who are sometimes affected by some type of illness that promotes disabilities.

[...] however, on the other hand the elderly are afflicted by chronic and evolutionary diseases that can generate disabilities and dependencies in daily living activities such as bathing eating hair combing dependencies on instrumental activities. [...] discrimination with the elderly, abandonment, substandard housing, lack of physical exercise, inadequate food and falls. [...] lack of a service aimed directly at the man as the prevention of prostate cancer closer to conviviality, etc.

\section{DISCUSSION}

Men have difficulty accessing health services, although they suffer more from severe health conditions when compared to women, in addition to dying more than the main causes of death (COURTENAY, 2000; LAURENTI et al, 2005; LUCK et al, 2000). The socialization of men, where care is not seen as a male practice can have a considerable impact on the demand for health services. The concept of masculinity in Western societies allows man to judge himself as immune to diseases, which he considers signs of fragility. Men seek services in extreme cases when they have to go into the hospital; which entails severe costs for the system, man and family (FIGUEIREDO, 2005; GOMES; NASCIMENTO; ARAUJO, 2007).

Studies carried out in order to know the health needs and identify the obstacles that impede the health needs of man, highlight the preventive health of the man with the examination for prostate cancer prevention, the increase of the number of doctors, to assist to all patients seeking services, the shame of being exposed and the impatience faced by men during waiting for care, consequently the lack of time to dedicate their health, attributed to the work regime and the lack of resolution of needs of health (MOREIRA; GOMES; RIBEIRO, 2016).

It is worth noting that despite the efforts of the health professionals of the Family Health Strategy to provide good assistance in the implementation of the Policy of Integral Attention to Human Health in the elderly life cycle, it still faces many difficulties that generate discomfort and that will as well as their ability to act, because they have specific characteristics evidenced as a consequence of the socioeconomic factor and family life, such as the issue of housing in poor conditions, abandonment, inadequate food and falls (FIGUEIREDO, 2005; GOMES; NASCIMENTO; ARAUJO, 2007).

In relation to the health professionals' performance in the FHT in relation to human health, they relate the quality of care, attention, access of the population to the FHT, activities developed by the team in attention to the health of the population. For the integral attention to the health of the man, the health professionals, for the most part, consider the National Policy of Integral Attention to the Health of the Man as a relevant subsidy to work actions directed to the masculine public. However, the professionals do not have sufficient support to carry out their actions, as well as, they do not know PNAISH in its entirety, in view of this, it is necessary to articulate ways to improve the professionals' knowledge through qualifications and qualifications (RAMOS; CALAIS; ZOTESSO, 2019).

Of the aspects that interfere in the attention to the health of the man, expose to the need to take better care of the health of the target public, they report again to the necessity of training course, to understand better and thus to be able to explain to the man how to take care of his own health.

In the narrative of the health care of the elderly, it is difficult for men to seek health services for consultations and examinations, as well as to suggest more medical specialties, among them the Urologist, due to the non-existence of this specialty in the municipality.

Men have difficulties to be heard adequately in health care units, so they rarely attend these places. In addition, the fact that female professionals dominate most health services and professions can be associated as a factor preventing men from accessing services, especially in order to treat sexuality (GOMES; NASCIMENTO; ARAUJO, 2007).

Thus, our results show that in general, they lack viable strategies to sensitize and attract these men to health services. The study made it possible to understand the complexity and specificity of health care for elderly people, the actions carried out by the health professionals of the FHT, the coping of difficulties and processes unrelated to their resolution skills, as well as the need for greater attention in the training of health professionals for the implementation of the National Policy of 
Elderly health...

Integral Attention to Human Health in the life cycle of the elderly. We also take in account the coverage of the qualitative approach, which limits the comprehensiveness of the results to the perception of the participants.

\section{CONCLUSIONS}

With regard to the influences of the professional training process for action in the Family Health Strategy related to the Health of the Aged Man, they suggest improvement of knowledge through education policy for vocational training.
SILVA, M. N. P. et al.

Participants also refer to the need for training. These factors may contribute to the acquisition of knowledge related to vocational training.

In relation to the Assistance to the Health of Elderly Men, it established two aspects: the first one describes the way in which the health professionals approach the users to provide the assistance, guiding the man to seek the health services; and the second one deals with the difficulties encountered to develop quality care, such as a lack of resources and training, a lack of medical specialties, and the difficulty of men seeking health services.

RESUMO: Identificar as influências do processo de formação profissional para atuação na Estratégia Saúde da Família (ESF) relacionada à saúde do homem idoso; expor ações desenvolvidas na ESF na implementação da Política Nacional de Atenção Integral à Saúde do Homem Idoso. Pesquisa descritiva exploratória, realizada com 20 profissionais, de um município do Nordeste brasileiro de outubro a dezembro de 2014. A coleta de dados foi realizada por meio de questionário, a seguir os depoimentos foram processados no software IRaMuTeQ, analisados pela Classificação Hierárquica Descendente. Emergiram três classes: Influências do processo de formação profissional na atenção à saúde do homem idoso; Assistência à saúde do homem idoso; Ações desenvolvidas na estratégia de saúde da família na implementação da política nacional de atenção integral à saúde do homem idoso. Os achados sugerem melhoria de conhecimento, dispõe sobre a falta de recursos e especialidades médicas, evidenciou a complexidade das ações desenvolvidas pelos profissionais de saúde.

PALAVRAS- CHAVE: Formação profissional. Saúde do homem. Idoso. Atenção Primária à Saúde. Pesquisa qualitativa.

\section{REFERENCES}

AGUIAR, R. S.; SANTANA, D. C.; SANTANA, P. C. A percepção do enfermeiro da estratégia saúde da família sobre a saúde do homem. Revista de enfermagem do centro oeste mineiro, v. 5, n. 3, 2016.

ALELUIA, I. R. S et al. Coordenação do cuidado na atenção primária à saúde: estudo avaliativo em município sede de macrorregião do nordeste brasileiro. Ciência \& Saúde Coletiva, v. 22, p. 1845-1856, 2017. https://doi.org/10.1590/1413-81232017226.02042017

BRASIL. Ministério da Saúde. Portaria n⿳ 2.488, de 21 de outubro de 2011. Aprova a Política Nacional de Atenção Básica, estabelecendo a revisão de diretrizes e normas para a organização da Atenção Básica, para a Estratégia Saúde da Família (ESF) e o Programa de Agentes Comunitários de Saúde (PACS). Brasília, DF. 2011. Disponível em: http://bvsms.saude.gov.br/bvs/saudelegis/gm/2011/prt2488_21_10_2011.html.

COURTENAY, W. H. Constructions of masculinity and their influence on men's well-being: a theory of gender and health. Soc Sci Med, v.50, p: 1385-401, 2000. https://doi.org/10.1016/S0277-9536(99)00390-1

FERRAZ, D.; KRAICZYK, J. Gênero e Políticas Públicas de Saúde-construindo respostas para o enfrentamento das desigualdades no âmbito do SUS. Rev Psicol UNESP, v. 9, n. 1, p. 70-82, 2017.

FIGUEIREDO, W. Assistência à saúde dos homens: um desafio para os serviços de atenção primária. Ciênc Saúde Coletiva, v.10, p, 105-9, 2005. https://doi.org/10.1590/S1413-81232005000100017 
Elderly health...

SILVA, M. N. P. et al.

GOMES, R.; NASCIMENTO, E. F.; ARAUJO, F. C. Por que os homens buscam menos os serviços de saúde do que as mulheres? As explicações de homens com baixa escolaridade e homens com ensino superior. Cad.

Saúde Pública, Rio de Janeiro, v. 23, n. 3, p. 565-574, Mar. 2007. https://doi.org/10.1590/S0102-

311X2007000300015

JESUS, G. J. et al. Difficulties of living with HIV/Aids: Obstacles to quality of life. Acta paul. enferm., São Paulo, v. 30, n. 3, p. 301-307, maio 2017. https://doi.org/10.1590/1982-0194201700046

LAURENTI, R. et al. Perfil epidemiológico da morbi-mortalidade masculina. Ciênc Saúde Coletiva, v.10, p. 35-46, 2005. https://doi.org/10.1590/S1413-81232005000100010

LUCK, M. et al Men's health: perspectives, diversity and paradox. London: Blackwell Sciences; 2000.

MATOS, M. C. B. et al. Nursing professionals' knowledge regarding the management of waste produced in primary health care. Rev. Bras. Enferm., Brasília, v. 71, supl. 6, p. 2728-2734, 2018.

https://doi.org/10.1590/0034-7167-2018-0308

MATOS, M. C. B. et al. "Control de la Infección es Señal de Seguridad": Discusiones a partir de la Perspectiva de Estudiantes. Revista de Pesquisa: Cuidado é Fundamental, v. 10, n. 3, p. 640-646, 25 set. 2018. https://doi.org/10.9789/2175-5361.2018.v10i3.640-646

MINAYO, M. C. S. et al. Lições aprendidas na avaliação de um programa brasileiro de atenção a idosos vítimas de violência. Interface-Comunicação, Saúde, Educação, v. 19, p. 171-182, 2015. https://doi.org/10.1590/1807-57622014.0427

MOREIRA, M. C. N.; GOMES, R.; RIBEIRO, C. R. E agora o homem vem?! Estratégias de atenção à saúde dos homens. Cadernos de Saúde Pública, v. 32, p. e00060015, 2016. https://doi.org/10.1590/0102$311 \times 00060015$

QUEIROZ, A. A. F. L. N.; SOUSA, A. F. L. Fórum PrEP: um debate on-line sobre uso da profilaxia préexposição no Brasil. Cad. Saúde Pública, Rio de Janeiro, v. 33, n. 11, e00112516, nov. 2017. https://doi.org/10.1590/0102-311x00112516

QUEIROZ, A. A. F. L. N. et al. Knowledge about HIV/AIDS and implications of establishing partnerships among Hornet ${ }^{\circledR}$ users. Rev. Bras. Enferm., Brasília, v. 71, n. 4, p. 1949-1955, Aug. 2018. https://doi.org/10.1590/0034-7167-2017-0409

RAMOS, A. C.; CALAIS, S. L.; ZOTESSO, M. C. Convivência do familiar cuidador junto a pessoa com transtorno mental. Contextos Clínicos, v. 12, n. 1, p. 282-302, 2019. https://doi.org/10.4013/ctc.2019.121.12

RIBEIRO, C. R.; GOMES, R.; MOREIRA, M. C. N. Encontros e desencontros entre a saúde do homem, a promoção da paternidade participativa e a saúde sexual e reprodutiva na atenção básica. Physis, v. 27, p. 41-60, 2017. https://doi.org/10.1590/s0103-73312017000100003

RODRIGUES, P. S. et al. Acidente ocupacional entre profissionais de enfermagem atuantes em setores críticos de um pronto-socorro. Esc. Anna Nery, Rio de Janeiro, v. 21, n. 2, e20170040, 2017.

SHUBERT, C. O. et al. A promoção da saúde do homem no contexto da atenção primária em saúde. Ciência Atual, v. 11, n. 1, 2018. 